\title{
Mengidentifikasi Unsur Intrinsik Cerita Pendek Menggunakan Strategi PAIKEM di Sekolah Menengah Atas
}

\section{Identifying the Intrinsic Elements of the Short Story Using the PAIKEM Strategy in Senior High School}

\section{Ade Yaya Kusyaeri ${ }^{1}$}

Artikel diterima editor tanggal 26-02-2021, disetujui untuk dipublikasikan tanggal 26-05-2021

Doi: $x x x x x-x x x x x$

\begin{abstract}
Abstrak
Kemampuan peserta didik dalam pembelajaran mengidentifikasi unsur intrinsik cerita pendek (cerpen) masih rendah. Penelitian ini bertujuan untuk: 1) mendeskripsikan kemampuan peserta didik dalam mengidentifikasi unsur intrinsik cerpen Hadiah Seratus Cambukan karya Habiburrahman El Shirazy dan 2) keefektifan strategi PAIKEM dalam pembelajaran mengidentifikasi unsur intrinsik cerpen. Penelitian eksperimen ini menggunakan quasi experiment dengan desain One-group pretestposttest design. Data dikumpulkan dengan teknik kepustakaan dan teknik tes (pretest dan posttest). Populasi seluruh siswa kelas XI SMA Negeri 1 Maja sebanyak 144 orang peserta didik yang terdiri atas enam kelas. Sampel yang penulis gunakan adalah kelas XI IPS 3 dengan jumlah sebanyak 24 orang peserta didik yang terpilih melalui teknik probability sampling jenis simple random sampling. Berdasarkan hasil pengolahan data dan pembahasan menunjukkan bahwa kemampuan peserta didik mengalami peningkatan nilai rata-rata sebesar 8,2 atau 8,2\% setelah menggunakan strategi PAIKEM.
\end{abstract}

Kata kunci: Hadiah Seratus Cambukan, pembelajaran cerita pendek, PAIKEM

\begin{abstract}
Students' ability to identify the intrinsic elements of short stories (short stories) is still low. This study aims to: 1) describe the ability of students in identifying the intrinsic elements of Habiburrahman EI Shirazy's short stories, and 2) the effectiveness of the PAIKEM strategy in learning to identify the intrinsic elements of short stories. This experimental research used a quasi-experiment with Onegroup pretest-posttest design. Data were collected using literature techniques and test techniques (pretest and posttest). The population of all class XI students of SMA Negeri 1 Maja was 144 students. The author's sample is class XI IPS 3, with a total of 24 students who were selected through a probability sampling technique. Based on the results of data processing and discussion, it shows that students' ability has increased by an average value of 8.2 or $8.2 \%$ after using the PAIKEM strategy.
\end{abstract}

Keywords: Hadiah Seratus Cambukan, Learning of short story, PAIKEM

${ }^{1}$ Ade Yaya Kusyaeri, SMKN 5 Kuningan, adeyayakusyaeri22@gmail.com 


\section{Pendahuluan}

Pembelajaran yaitu proses transfer ilmu pengetahuan dan kemampuan baru yang direncanakan dan disusun sedemikian rupa untuk membantu peserta didik dalam proses belajar. Perencanaan dan penyusunan proses pembelajaran ini dimaksudkan untuk memudahkan guru dalam mentransfer ilmu pengetahuan kepada peserta didik serta bertujuan supaya proses pembelajaran yang dilakukan dapat tersusun secara cermat dan jelas sesuai dengan tujuan pembelajaran. Upaya meningkatkan keberhasilan pembelajaran merupakan tantangan yang selalu dihadapi oleh setiap guru. Seorang guru dituntut untuk menciptakan proses pembelajaran yang sesuai dengan situasi dan kondisi pembelajaran (Mulyaningsih, dkk, 2016). Situasi dan kondisi pembelajaran yang dilakukan oleh setiap guru di setiap sekolah berbeda-beda. Hal tersebut disebabkan oleh perbedaan sarana dan prasarana lembaga di sekolahnya masing-masing.

Kemampuan memilih, menentukan, serta mengembangkan strategi pembelajaran perlu dimiliki oleh setiap guru. Selain itu, seorang guru juga harus memiliki kemampuan dalam memanfaatkan multimedia dan berbagai metode pembelajaran. Secara implisit hal tersebut mengandung arti bahwa dalam kegiatan pembelajaran terdapat kegiatan memilih, menentukan, dan mengembangkan metode untuk mencapai hasil yang diinginkan. Pemilihan, penentuan, dan pengembangan metode ini didasarkan pada kondisi pembelajaran yang ada (Mulyaningsih, dkk, 2018).

Keberhasilan proses pembelajaran dapat ditentukan dengan ketiga hal tersebut yaitu kemampuan memilih, menentukan, serta mengembangkan strategi pembelajaran yang memungkinkan terjadinya proses belajar mengajar yang efektif dan efisien sehingga dapat mencapai hasil yang sesuai dengan tujuan pembelajaran. Pernyataan tersebut sesuai dengan pendapat yang dikemukakan oleh Kemp dalam Sanjaya (2008) 'menjelaskan bahwa strategi pembelajaran adalah suatu kegiatan pembelajaran yang harus dikerjakan guru dan peserta didik agar tujuan pembelajaran dapat dicapai secara efektif dan efisien'.

Menanggapi pernyataan di atas, yang sering menjadi kendala bagi seorang guru dalam memilih, menentukan, dan mengembangkan strategi pembelajaran yang sesuai adalah sebagai berikut, di antaranya: (1) kemampuan memilih, menentukan, dan mengembangkan metode pembelajaran masih rendah, (2) kemampuan menggunakan multimedia dalam pembelajaran masih kurang, (3) pendekatan pembelajaran yang digunakan masih berpusat pada guru, sedangkan pendekatan pembelajaran yang berpusat pada peserta didik masih jarang digunakan, dan (4) guru kurang kreatif dalam menyusun strategi pembelajaran.

Beberapa kelemahan yang dimiliki oleh guru di atas, dapat berakibat pada kondisi peserta didik saat proses belajar mengajar berlangsung, di antaranya: (1) peserta didik jenuh dan bosan dengan metode pembelajaran yang kurang inovasi, (2) peserta didik kurang semangat dalam belajar, (3) peserta didik kurang aktif dalam proses belajar mengajar bahkan peserta didik cenderung pasif, dan (4) peserta didik kurang berminat dan tertarik dengan proses pembelajaran yang diberikan.

Mengapresiasi karya sastra diawali dengan mengidentifikasi unsur-unsur yang terkandung dalam karya sastra, baik unsur intrinsik ataupun ekstrinsiknya. Pembelajaran mengidentifikasi unsur intrinsik cerpen di sekolah belum optimal. Hal ini disebabkan oleh beberapa faktor, di antaranya: (1) kurang tersedianya sumber pembelajaran mengenai identifikasi unsur intrinsik cerpen, khususnya sumber-sumber media cetak (2) kurang diberikannya kesempatan kepada peserta didik untuk mengidentifikasi unsur intrinsik cerpen, kebanyakan pembelajaran masih bersifat teori bukan praktik, (3) kurang tersedianya cerpen-cerpen yang mendidik serta dapat digunakan dalam pembelajaran mengidentifikasi unsur intrinsik, dan (4) sesuai atau tidaknya seorang guru dalam memilih, menentukan, dan mengembangkan strategi pembelajaran dalam proses pembelajaran mengidentifikasi unsur intrinsik cerpen.

Kegagalan pembelajaran mengidentifikasi unsur intrinsik cerpen peserta didik cukup besar. Hal itu disebabkan oleh: (1) peserta didik kurang tertarik dan berminat untuk membaca karya sastra, khususnya cerpen, (2) peserta didik belum memahami tema atau pokok pikiran yang terkandung di 


\section{JGI: JURNAL GURU INDONESIA}

2021, 1(1), hlm. 10 - 19

https://jurnal.ppjb-sip.org/index.php/igi/index

E-ISSN: XXXX-XXXX | DOI: $\mathrm{xxxxx-xxxxx}$

dalam cerpen, (3) peserta didik belum mampu menemukan pesan atau amanat yang tersurat maupun tersirat dalam cerpen yang dibacanya, dan (4) ketika peserta didik diajak untuk mengapresiasi karya sastra, mereka kadang tidak serius, terkesan menyepelekan sehingga keadaan kelas menjadi tidak kondusif.

Pemilihan strategi PAIKEM (pembelajaran yang aktif, inovatif, kreatif, efektif, dan menyenangkan) merupakan tantangan bagi guru demi tercapainya proses belajar mengajar yang aktif dan komunikatif. Guru berusaha untuk meningkatkan kualitas dirinya. Perencanaan dan penyajian proses pembelajaran yang ditunjang dengan strategi pembelajaran yang tepat dan didukung oleh metode serta media pembelajaran yang baik, tentu akhirnya mendapat hasil yang baik pula. Begitu sebaliknya apabila perencanaan dan penyajian proses pembelajaran terhadap peserta didik dilakukan dengan asal-asalan maka hasilnya juga pasti asal-asalan dan tujuan pembelajaran tidak tercapai.

Efektivitas pembelajaran mengidentifikasi unsur intrinsik cerpen peserta didik masih rendah. Oleh karena itu, di dalam proses pembelajaran perlu adanya interaksi yang intensif antara peserta didik dengan guru, peserta didik dengan peserta didik, dan peserta didik dengan sumber belajar. Selain hal tersebut dalam pembelajaran mengidentifikasi unsur intrinsik cerpen, strategi pembelajaran yang digunakan kurang bervariasi. Penggunaan strategi PAIKEM (pembelajaran yang aktif, inovatif, kreatif, efektif, dan menyenangkan) merupakan salah satu solusi yang harus dicoba dan dikembangkan dalam proses pembelajaran mengidentifikasi unsur intrinsik cerpen.

Berdasarkan uraian di atas, penulis tertarik ingin mengetahui lebih jauh permasalahan tersebut dengan membuat karya tulis berupa penelitian tindakan kelas yang berjudul Pembelajaran Mengidentifikasi Unsur Intrinsik Cerpen Hadiah Seratus Cambukan Karya Habiburrahman El Shirazy dengan Menggunakan Strategi PAIKEM di Kelas XI SMA Negeri 1 Maja.

\section{Metode penelitian}

Populasi penelitian di Kelas XI SMA Negeri 1 Maja Tahun Ajar 2013/2014, yaitu sebanyak enam kelas dari delapan kelas jumlah keseluruhannya. Jumlah populasi sebanyak 144 orang peserta didik yang terdiri dari 56 orang peserta didik laki-laki dan 88 orang peserta didik perempuan. Kemudian dari jumlah populasi enam kelas tersebut dipilih satu kelas sebagai sampel. Sampel diambil dengan teknik ssmpel random sampling (Sugiyono, 2010). Sampel dalam penelitian ini adalah peserta didik Kelas XI IPS 3 SMA Negeri 1 Maja, dengan jumlah sebanyak 24 orang peserta didik, yang terdiri dari 9 orang peserta didik laki-laki dan 16 orang peserta didik perempuan.

Salah satu hal yang penting dalam sebuah penelitian adalah adanya data penelitian. Data yang diperlukan dalam penelitian ini merupakan perolehan hasil tes awal (pretest) dan hasil tes akhir (posttest) dari pembelajaran mengidentifikasi unsur intrinsik cerpen Hadiah Seratus Cambukan karya Habiburrahman EI Shirazy dengan menggunakan strategi PAIKEM di Kelas XI SMA Negeri 1 Maja.

Teknik pengumpulan data yang digunakan penulis dalam penelitian ini adalah sebagai berikut.

Teknik Kepustakaan

Penulis menggunakan teknik ini untuk menelaah buku-buku sumber yang ada hubungannya dengan masalah yang sedang diteliti, untuk mendapat wawasan ilmu pengetahuan mengenai unsur intrinsik cerpen, teori-teori mengenai strategi pembelajaran yang aktif, inovatif, kreatif, efektif, dan menyenangkan, serta dapat dijadikan landasan atau pedoman dalam melaksanakan penelitian. Hal tersebut di atas sesuai dengan yang dikemukakan oleh Anggoro (2008) "Tinjauan pustaka adalah kegiatan yang meliputi mencari, membaca, dan menelaah laporan-laporan penelitian dan bahan pustaka yang memuat teori-teori yang relevan dengan penelitian yang akan dilakukan". Secara umum, tinjauan pustaka bertujuan untuk mengembangkan pemahaman dan wawasan yang menyeluruh tentang penelitian-penelitian yang pernah dilakukan dalam suatu topik.

Teknik Tes 
Tes sebagai instrumen pengumpulan data adalah serangkaian pertanyaan atau latihan yang digunakan untuk mengukur keterampilan pengetahuan, intelegensi, kemampuan atau bakat yang dimiliki individu atau kelompok". Teknik tes digunakan untuk mengukur pemahaman peserta didik dalam mengidentifikasi unsur intrinsik cerpen. Penulis menggunakan dua macam tes yaitu tes awal (pretest) dan tes akhir (posttest). Lebih jelasnya, Djamarah (2010) menjelaskan sebagai berikut. Tes awal (pretest), yaitu tes pada peserta didik yang dilaksanakan sebelum pelajaran dimulai atau sebelum proses pembelajaran. Tes akhir (posttest), yaitu tes yang diberikan setelah proses pembelajaran berakhir.

Teknik Pengolahan Data

Teknik pengolahan data yang digunakan dalam penelitian ini adalah teknik kuantitatif. Kegiatan analisis data dengan menggunakan pendekatan kuantitatif, maka teknik analisis data ini berkenaan dengan penghitungan untuk menjawab rumusan masalah dan pengujian hipotesis yang diajukan. Pengolahan data bertujuan untuk mengubah data mentah dari hasil pengukuran menjadi data yang sebenarnya sehingga data tersebut dapat dikaji lebih lanjut. Setelah data hasil pretest dan posttest terkumpul, selanjutnya penulis akan mengolah data dengan menggunakan teknik penghitungan statistik, sehingga dapat ditemukan korelasinya. Teknik pengolahan data yang digunakan adalah sebagai berikut.

Teknik Tes Tulis

Menurut Somantri (2010) teknik tes tulis persentase yaitu untuk memperoleh data berapa persen (\%) kemampuan yang telah dicapai peserta didik dengan kriteria sebagai berikut.

$\begin{array}{ll}0 \% & : \text { tidak sedikitpun } \\ 1 \%-24 \% & : \text { hampir tidak ada } \\ 25 \%-49 \% & : \text { hampir separuhnya } \\ 50 \% & : \text { separuhnya } \\ 51 \%-74 \% & : \text { lebih dari separuhnya } \\ 75 \%-99 \% & : \text { hampir seluruhnya } \\ 100 \% & \text { : seluruhnya }\end{array}$

\section{Rumus Korelasi Product Moment}

Rumus korelasrasi product moment digunakan sebagai pengukuran dua variabel yang dikorelasikan semuanya dalam bentuk data interval atau rasio. Teknik ini digunakan untuk mengetahui efektivitas penggunaan strategi PAIKEM dalam pembelajaran mengidentifikasi unsur intrinsik cerpen Hadiah Seratus Cambukan karya Habiburrahman El Shirazy di Kelas XI SMA Negeri 1 Maja. Sudjana dan Ibrahim (2001) menuliskan rumus korelasi product moment sebagai berikut.

$$
r=\frac{\mathrm{n} \cdot \sum \mathrm{XY}-\left(\sum \mathrm{X}\right)\left(\sum \mathrm{Y}\right)}{\sqrt{\left\{\mathrm{n} \sum \mathrm{X}^{2}-\left(\sum \mathrm{X}\right)^{2}\right\}\left\{\mathrm{n} \sum \mathrm{Y}^{2}-\left(\sum \mathrm{Y}\right)^{2}\right\}}}
$$

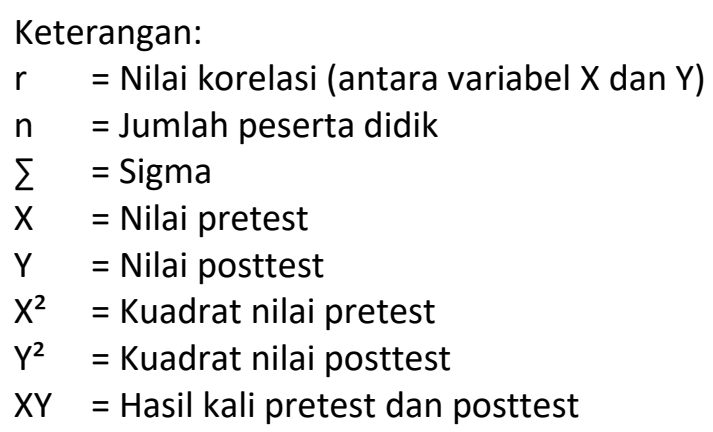

Interpretsi Koefisien Korelasi 


\section{JGI: JURNAL GURU INDONESIA}

2021, 1(1), hlm. 10 - 19

https://jurnal.ppjb-sip.org/index.php/igi/index

E-ISSN: XXXX-XXXX | DOI: $x x x x x-x x x x x$

Sudjana dan Ibrahim (2001) mengemukakan pedoman pemberian interpretasi koefisien korelasi sebagai berikut.
$0,000-0,200$
$=$ korelasi rendah sekali
0,200
- 0,400
$=$ korelasi kecil
0,400
- 0,700
= korelasi cukup
0,700
- 0,900
0,900
- ke atas
$=$ korelasi tinggi
$=$ korelasi sangat tinggi

\section{Pembahasan}

\section{Pelaksanaan Strategi PAIKEM}

Pelaksanaan strategi PAIKEM yang dilakukan dan kembangkan dalam kegiatan pembelajaran mengidentifikasi unsur intrinsik cerpen Hadiah Seratus Cambukan karya Habiburrahman El Shirazy di Kelas XI IPS 3 SMA Negeri 1 Maja dapat penulis paparkan sebagai berikut.

Pelaksanaan pembelajaran aktif dalam pembelajaran mengidentifikasi unsur intrinsik cerpen Hadiah Seratus Cambukan karya Habiburrahman El Shirazy yang penulis terapkan dalam pembelajaran adalah sebagai berikut. Setelah melakukan kegiatan pretest pada pertemuan pertama, penulis mengarahkan peserta didik untuk mencari dan mempelajari materi tentang unsur intrinsik cerpen. Materi dapat diperoleh dari buku ataupun browsing internet. Dengan demikian, peserta didik aktif mencari dan memahami materi pembelajaran secara mandiri. Setelah hal tersebut dilakukan ternyata hasilnya cukup baik, secara umum peserta didik telah mampu memahami materi.

Ketika pelaksanaan pembelajaran berlangsung, penulis berusaha supaya kegiatan pembelajaran berlangsung secara komunikatif. Salah satunya penulis menampilkan contoh video cerpen untuk diidentifikasi unsur intrinsiknya. Secara langsung penulis bertanya kepada peserta didik mengenai unsur intrinsik yang terdapat pada video tersebut. Penulis mengajukan pertanyaan kepada peserta didik dengan ramah dan bersahabat. Hal ini membuat peserta didik tidak merasa takut dalam bertanya atau mengemukakan pendapatnya.

Misalnya penulis bertanya "Setelah kalian menyaksikan video tersebut, coba kalian sebutkan alur apakah yang terdapat dalam cerita tersebut? Siapa yang bisa silakan acungkan tangan!" Setelah beberapa peserta didik menjawab pertanyaan tersebut kemudian penulis menjelaskan jenis alur yang terdapat dalam cerita tersebut, penulis berusaha menguatkan pendapat-pendapat yang telah dikemukakan sebelumnya oleh peserta didik. Setelah itu baru penulis menjelaskan mengenai pengertian alur, jenis alur, dan sebagainya. Hal tersebut terus menerus dilakukan hingga target unsur intrinsik cerpen disampaikan semuanya yaitu mengenai alur, latar, penokohan, dan amanat. Dengan demikian, proses pembelajaran menjadi lebih komunikatif sementara itu peserta didik aktif dalam mengemukakan pendapat serta mengungkapkan pertanyaan-pertanyaan apabila mereka kurang mengerti.

Pada kegiatan evaluasi atau penugasan, penulis menggunakan metode kerja kelompok. Hal ini dimaksudkan supaya peserta didik lebih aktif lagi dalam pembelajaran. Penulis membiarkan peserta didik untuk berdiskusi dan berargumentasi mengenai tugas yang diberikan kepada mereka. Penulis hanya berperan sebagai pengawas, pembimbing, dan pengatur jalannya kerja kelompok. Penulis tidak ikut campur secara langsung dalam kegiatan tersebut. Artinya kegiatan tersebut hanya dilakukan oleh peserta didik dan untuk peserta didik sendiri. Dengan demikian secara keseluruhan peserta didiklah yang lebih aktif dalam pembelajaran, penulis hanya berfungsi sebagai pengarah dan pengontrol pelaksanaan pembelajaran saja.

Menurut penulis, ketiga kegiatan pembelajaran di atas seperti menyuruh peserta didik untuk mencari dan memahami materi sebelum pembelajaran, melakukan tanya jawab dengan ramah dan 
bersahabat, ditambah lagi dengan kegiatan kerja kelompok efektif membuat peserta didik belajar dengan aktif.

Pelaksanaan pembelajaran inovatif dalam pembelajaran mengidentifikasi unsur intrinsik cerpen Hadiah Seratus Cambukan karya Habiburrahman El Shirazy yang penulis terapkan dalam pembelajaran adalah sebagai berikut. Sebelum melaksanakan pembelajaran penulis mempersiapkan beberapa alat bantu untuk mempermudah penulis dalam kegiatan pembelajaran di antaranya penulis menyediakan notebook, infocus, dan pengeras suara. Ketiga alat tersebut sangat membantu penulis dalam kegiatan pembelajaran. Notebook penulis gunakan sebagai sumber pembelajaran di dalamnya terdapat materi pembelajaran, video cerpen, rekaman pembacaan cerpen, dan sebagainya. Kemudian infocus berguna untuk memantulkan materi dan video ke papan tulis, sehingga peserta didik dapat dengan mudah melihat atau memperhatikan materi pembelajaran yang ditampilkan. Sementara itu pengeras suara dapat membantu peserta didik dalam menyimak setiap tuturan atau percakapan yang terdapat dalam video maupun rekaman.

Sama halnya dengan alat bantu pembelajaran di atas, penulis juga menggunakan berbagai media dalam pembelajaran. Misalnya penulis menggunakan media visual, media audio, dan media audio visual. Media visual penulis gunakan dalam penyampaian materi pembelajaran yaitu dengan menggunakan media power point. Selanjutnya, media audio penulis gunakan dalam kegiatan evaluasi dan penugasan dalam mengidentifikasi unsur intrinsik cerpen melalui kegiatan menyimak rekaman pembacaan cerpen. Sementara itu, media audio visual penulis gunakan dalam mencontohkan bagaimana cara mengidentifikasi unsur intrinsik cerpen yaitu melalui video cerpen. Menurut penulis penggunaan alat bantu dan multi media ini merupakan cara yang cukup inovatif dalam membelajarkan peserta didik karena tidak dapat dipungkiri saat ini guru masih jarang menggunakan berbagai alat bantu dan media pembelajaran dalam kegiatan pelaksanaan pembelajarannya (Mulyaningsih \& Itaristanti, 2018).

Pelaksanaan pembelajaran kreatif dalam pembelajaran mengidentifikasi unsur intrinsik cerpen Hadiah Seratus Cambukan karya Habiburrahman El Shirazy yang penulis terapkan dalam pembelajaran adalah sebagai berikut. Seperti telah dikemukakan di atas, dalam pelaksanaan pembelajaran penulis menggunakan metode diskusi kelompok, agar peserta didik tidak bosan dan jenuh dengan metode kerja kelompok yang biasa dilakukan. Maka dari itu, penulis menggunakan metode cooperative learning tipe jigsaw. Jigsaw adalah suatu tipe pembelajaran kooperatif yang terdiri dari beberapa anggota dalam satu kelompok yang bertanggung jawab atas penguasaan bagian materi belajar dan mampu mengajarkan materi tersebut kepada anggota lain dalam kelompoknya. Melalui penggunaan jigsaw ini pembelajaran kelompok menjadi lebih aktif. Hal ini dikarenakan peserta didik harus memahami dan menguasai satu permasalahan, kemudian permasalahan tersebut harus diajarkan atau disampaikan kembali ke peserta didik lainnya di kelompok mereka masingmasing secara bergiliran sehingga semua anggota kelompok tersebut dapat memahami keseluruhan materi atau permasalahan. Supaya proses pembelajaran dapat tercapai dengan baik, maka sumber dan materi pembelajaran harus dibuat dan disusun sendiri oleh pengajar yang disesuaikan dengan situasi, kondisi, dan tujuan pembelajaran. Oleh karena itu, penulis membuat rekaman pembacaan cerpen sendiri yang disesuaikan dengan judul penelitian yaitu menggunakan cerpen Hadiah Seratus Cambukan karya Habiburrahman El Shirazy.

Menurut penulis, seorang guru harus dapat memanfaatkan segala potensi yang ada pada dirinya dalam membelajarkan peserta didiknya. Artinya pembelajaran yang kreatif tidak hanya menitikberatkan pada pengembangan kemampuan berpikir kreatif pada peserta didik saja, tetapi guru sebagai fasilitator pun dituntut untuk senantiasa kreatif dalam merancang pembelajaran guna memenuhi beragam tingkat kemampuan peserta didik di dalam kelas.

Pelaksanaan pembelajaran efektif dalam pembelajaran mengidentifikasi unsur intrinsik cerpen Hadiah Seratus Cambukan karya Habiburrahman El Shirazy yang penulis terapkan dalam pembelajaran adalah sebagai berikut. Ketika pelaksanaan pembelajaran penulis berusaha untuk fokus pada tujuan pembelajaran yaitu membatasi pengajaran yang diberikan kepada peserta didik. 


\section{JGI: JURNAL GURU INDONESIA}

2021, 1(1), hlm. 10 - 19

https://jurnal.ppjb-sip.org/index.php/jgi/index

E-ISSN: XXXX-XXXX | DOI: $\mathrm{xxxxx-Xxxxx}$

Penulis hanya memberikan contoh cara mengidentifikasi unsur intrinsik cerpen serta hanya mengulas dan membahas materi mengenai alur, penokohan, latar, dan amanat saja tidak meluas pada materi yang lainnya. Sementara itu, tujuan pembelajaran yang ingin dicapai yaitu. (1) Peserta didik dapat mengidentifikasi alur, penokohan, latar, dan amanat cerpen yang didengar secara kritis dan bertanggung jawab; (2) Peserta didik dapat mendiskusikan alur, penokohan, latar, dan amanat dari cerpen yang didengar secara kritis dan bertanggung jawab. Penulis menerapkan pembelajaran yang berpusat pada peserta didik. Pembelajaran yang berpusat pada peserta didik yaitu pembelajaran yang membuat peserta didik aktif dalam belajar. Penulis hanya berperan sebagai fasilitator dan pengarah pembelajaran. Hal ini penulis lakukan karena pembelajaran yang baik adalah pembelajaran yang membuat peserta didik dapat menemukan dan memecahkan masalahnya secara mandiri. Penulis selalu memberikan apresiasi kepada peserta didik yang berani untuk berbicara dan mengemukakan pendapatnya serta selalu memotivasi peserta didik yang lainnya untuk lebih aktif lagi dalam belajar. Pemberian apresiasi kepada peserta didik yang aktif dirasakan perlu dilakukan oleh guru untuk memicu motivasi dan semangat peserta didik yang lainnya untuk berusaha menjadi yang lebih baik lagi.

Salah satu cara untuk memberikan semangat atau motivasi peserta didik yang sederhana yaitu dengan cara memberi tepuk tangan. Apabila peserta didik melakukan kesalahan jangan langsung memberikan vonis tetapi alangkah baiknya jika diberikan arahan dan bimbingan supaya ia lebih baik lagi. Menurut penulis pembelajaran yang efektif yaitu pembelajaran yang mudah dipahami, terhindar dari berbagai ancaman, hambatan, dan gangguan serta dapat ditunjukkan manakala pembelajaran tersebut telah mencapai tujuan pembelajaran. Penulis dapat menyimpulkan bahwa ketiga cara di atas dapat meningkatkan kemampuan belajar peserta didik.

Pelaksanaan pembelajaran yang menyenangkan dalam mengidentifikasi unsur intrinsik cerpen Hadiah Seratus Cambukan karya Habiburrahman El Shirazy yang penulis terapkan dalam pembelajaran adalah sebagai berikut. Ketika pelaksanaan pembelajaran penulis menunjukkan sikap yang ramah dan bersahabat dengan demikian peserta didik tidak merasa takut atau tegang di dalam pembelajaran. Situasi dan kondisi pembelajaran harus dibuat senyaman mungkin. Menurut penulis sikap seperti ini sangat penting dimiliki oleh seorang guru karena apabila peserta didik merasa tidak nyaman dalam belajar maka konsentrasi dan motivasi belajar mereka menurun. Penulis berusaha menyajikan materi pembelajaran dengan serius tapi dilakukan dengan santai artinya secara perlahanlahan. Hal ini dilakukan agar peserta didik tidak merasa bingung dengan materi yang kita berikan. Penulis juga memberikan pengajaran kepada peserta didik sedikit demi sedikit karena menurut penulis percuma juga jika kita mengajarkan terlalu banyak materi tetapi peserta didik tidak mengerti, artinya lebih baik sedikit dan disampaikan secara perlahan tetapi peserta didik paham dan mengerti dengan apa yang kita ajarkan. Ketika pelaksanaan pembelajaran berlangsung penulis tidak pernah memvonis peserta didik walaupun ia keliru dalam memberikan jawaban atau pendapatnya. Alangkah baiknya jika kita berusaha untuk memotivasi peserta didik agar lebih giat lagi dalam belajar, sehingga dikemudian hari ia tidak salah lagi dalam menjawab pertanyaan bukan malah dimarahi atau dibentak di depan peserta didik lainnya. Hal tersebut dapat memicu rasa takut dan malu dalam diri peserta didik. Rasa takut dan malu dapat menyebabkan kemalasan dalam kegiatan pembelajaran.

Uji Keefektifan

Tahapan uji keefektifan dilakukan dengan melakukan tes awal (pretest) dan tes akhir (posttest) kepada peserta didik mengenai pembelajaran mengidentifikasi unsur intrinsik cerpen Hadiah Seratus Cambukan karya Habiburrahman El Shirazy dengan menggunakan strategi PAIKEM. Adapun data yang diperoleh melalui kedua jenis tes tersebut adalah sebagai berikut. Data hasil pretest ini penulis peroleh pada hari Senin tanggal 28 April 2014 dalam pembelajaran mengidentifikasi unsur intrinsik cerpen Hadiah Seratus Cambukan karya Habiburrahman El Shirazy. 
Penelitian ini dilakukan di Kelas XI IPS 3 SMA Negeri 1 Maja pada jam kedua dan ketiga mata pelajaran Bahasa dan Sastra Indonesia. Jumlah sampel penelitian yang penulis teliti yaitu sebanyak 25 orang peserta didik. Namun kenyataannya, hanya terdapat 24 orang peserta didik yang mengikuti pretest dikarenakan satu orang peserta didik sakit.

Data hasil pretest diperlukan untuk menjawab rumusan masalah yang pertama yaitu bagaimana kemampuan peserta didik dalam mengidentifikasi unsur intrinsik cerpen di Kelas XI SMA Negeri 1 Maja Tahun Ajar 2013/2014 sebelum melakukan pembelajaran dengan menggunakan strategi PAIKEM. Hasil pretest peserta didik dalam mengidentifikasi unsur intrinsik cerpen Hadiah Seratus Cambukan karya Habiburrahman El Shirazy sebelum pembelajaran menggunakan strategi PAIKEM

Pengolahan data hasil tes awal (pretest) menunjukkan kemampuan peserta didik dalam mengidentifikasi unsur intrinsik cerpen Hadiah Seratus Cambukan karya Habiburrahman El Shirazy di Kelas XI SMA Negeri 1 Maja Tahun Ajar 2013/2014 sebelum pembelajaran menggunakan strategi PAIKEM. Pengolahan data pretest lebih jelasnya penulis gambarkan sebagai berikut. Sampel yang digunakan dalam penelitian ini yaitu kelas XI IPS 3 SMA Negeri 1 Maja dengan jumlah sebanyak 24 orang peserta didik yang terdiri dari 8 orang peserta didik laki-laki dan 16 orang peserta didik perempuan. Nilai rata-rata pretest adalah sebesar 71 atau $71 \%$ artinya kemampuan mengidentifikasi unsur intrinsik cerpen Hadiah Seratus Cambukan karya Habiburrahman El Shirazi sebelum pembelajaran menggunakan strategi PAIKEM menunjukkan kriteria lebih dari separuhnya peserta didik dapat mengidentifikasi unsur intrinsik cerpen dengan tepat. Nilai terendah pretest adalah 60 atau $60 \%$ artinya kemampuan mengidentifikasi unsur intrinsik cerpen Hadiah Seratus Cambukan karya Habiburrahman El Shirazy sebelum pembelajaran menggunakan strategi PAIKEM menunjukkan kriteria lebih dari separuhnya peserta didik tersebut dapat mengidentifikasi unsur intrinsik cerpen dengan tepat.

Nilai tertinggi pretest adalah 80 atau $80 \%$ artinya kemampuan mengidentifikasi unsur intrinsik cerpen Hadiah Seratus Cambukan karya Habiburrahman El Shirazy sebelum pembelajaran menggunakan strategi PAIKEM menunjukkan kriteria hampir seluruhnya peserta didik tersebut dapat mengidentifikasi unsur intrinsik cerpen dengan tepat. Nilai rata-rata pretest aspek pertanyaan 1 mengenai pemahaman terhadap alur yang terdapat dalam cerpen Hadiah Seratus Cambukan karya Habiburahman El Shirazy yaitu sebesar 2,1 artinya kemampuan peserta didik masih kurang. Nilai ratarata pretest aspek pertanyaan 2 mengenai pemahaman terhadap latar yang terdapat dalam cerpen Hadiah Seratus Cambukan karya Habiburahman El Shirazy yaitu sebesar 3,9 artinya kemampuan peserta didik sedang. Nilai rata-rata pretest aspek pertanyaan 3 mengenai pemahaman terhadap penokohan yang terdapat dalam cerpen Hadiah Seratus Cambukan karya Habiburahman El Shirazy yaitu sebesar 3,9 artinya kemampuan peserta didik sedang. Nilai rata-rata pretest aspek pertanyaan 4 mengenai pemahaman terhadap amanat yang terdapat dalam cerpen Hadiah Seratus Cambukan karya Habiburahman El Shirazy yaitu sebesar 4,3 artinya kemampuan peserta didik sudah baik.

Data hasil posttest ini penulis peroleh pada hari Senin tanggal 30 April 2014 dalam pembelajaran mengidentifikasi unsur intrinsik cerpen Hadiah Seratus Cambukan karya Habiburrahman El Shirazy. Penelitian ini dilakukan di Kelas XI IPS 3 SMA Negeri 1 Maja pada jam ketiga dan keempat mata pelajaran Bahasa dan Sastra Indonesia. Jumlah sampel penelitian yang penulis teliti yaitu sebanyak 25 orang peserta didik. Namun kenyataannya, hanya terdapat 24 orang peserta didik yang mengikuti posttest dikarenakan satu orang peserta didik sakit.

Data hasil posttest diperlukan untuk menjawab rumusan masalah yang kedua yaitu bagaimana kemampuan peserta didik dalam mengidentifikasi unsur intrinsik cerpen Hadiah Seratus Cambukan karya Habiburrahman El Shirazy di Kelas XI SMA Negeri 1 Maja Tahun Ajar 2013/2014 setelah pembelajaran dengan menggunakan strategi PAIKEM. Hasil posttest peserta didik dalam mengidentifikasi unsur intrinsik cerpen Hadiah Seratus Cambukan karya Habiburrahman El Shirazy setelah pembelajaran menggunakan strategi PAIKEM dapat dilihat melalui tabel di bawah ini. 


\section{JGI: JURNAL GURU INDONESIA}

2021, 1(1), hlm. 10 - 19

https://jurnal.ppjb-sip.org/index.php/jgi/index

E-ISSN: XXXX-XXXX | DOI: $\mathrm{xxxxx-xxxxx}$

Pengolahan data hasil tes akhir (posttest) di atas menunjukkan kemampuan peserta didik dalam mengidentifikasi unsur intrinsik cerpen Hadiah Seratus Cambukan karya Habiburrahman El Shirazy di Kelas XI SMA Negeri 1 Maja Tahun Ajar 2013/2014 setelah pembelajaran menggunakan strategi PAIKEM. Pengolahan data posttest lebih jelasnya penulis gambarkan sebagai berikut. Sampel yang digunakan dalam penelitian ini yaitu Kelas XI IPS 3 dengan jumlah sebanyak 24 orang peserta didik yang terdiri dari 8 orang peserta didik laki-laki dan 16 orang peserta didik perempuan. Nilai ratarata posttest adalah sebesar 79,2 atau $79,2 \%$ artinya kemampuan mengidentifikasi unsur intrinsik cerpen Hadiah Seratus Cambukan karya Habiburrahman El Shirazy sebelum pembelajaran dengan menggunakan strategi PAIKEM menunjukkan kriteria hampir seluruhnya peserta didik dapat mengidentifikasi unsur intrinsik cerpen dengan tepat. Nilai terendah posttest adalah 70 atau $70 \%$ artinya kemampuan mengidentifikasi unsur intrinsik cerpen Hadiah Seratus Cambukan karya Habiburrahman El Shirazy sebelum pembelajaran menggunakan strategi PAIKEM menunjukkan kriteria lebih dari separuhnya peserta didik tersebut dapat mengidentifikasi unsur intrinsik cerpen dengan tepat.

Nilai tertinggi posttest adalah 90 atau $90 \%$ artinya kemampuan mengidentifikasi unsur intrinsik cerpen Hadiah Seratus Cambukan karya Habiburrahman sebelum pembelajaran menggunakan strategi PAIKEM menunjukkan kriteria hampir seluruhnya peserta didik tersebut dapat mengidentifikasi unsur intrinsik cerpen dengan tepat. Nilai rata-rata posttest aspek pertanyaan 1 mengenai pemahaman terhadap alur dalam cerpen Hadiah Seratus Cambukan karya Habiburahman El Shirazy yaitu sebesar 2,7 artinya kemampuan peserta didik masih kurang. Nilai rata-rata posttest aspek pertanyaan 2 mengenai pemahaman terhadap latar dalam cerpen Hadiah Seratus Cambukan karya Habiburahman El Shirazy yaitu sebesar 4,9 artinya kemampuan peserta didik sudah baik. Nilai rata-rata posttest aspek pertanyaan 3 mengenai pemahaman terhadap penokohan dalam cerpen Hadiah Seratus Cambukan karya Habiburahman El Shirazy yaitu sebesar 4,1 artinya kemampuan peserta didik sudah baik. Nilai rata-rata posttest aspek pertanyaan 4 mengenai pemahaman terhadap amanat dalam cerpen Hadiah Seratus Cambukan karya Habiburahman El Shirazy yaitu sebesar 4,1 artinya kemampuan peserta didik sudah baik.

Pengolahan data dalam penelitian ini merupakan proses penghitungan data hasil pretest dan posttest. Hasil pengolahan data ini diharapkan dapat menjawab rumusan masalah serta menguji hipotesis penelitian. Penulis menggunakan rumus korelasi product moment untuk mengetahui keefektifan penggunaan strategi PAIKEM dalam pembelajaran mengidentifikasi unsur intrinsik cerpeh Hadiah Seratus Cambukan karya Habiburrahman El Shirazy. Pengolahan data tersebut dapat penulis gambarkan sebagai berikut. Berdasarkan penghitungan menggunakan rumus korelasi product moment di atas diperoleh $r=0,760$. Dengan demikian strategi PAIKEM efektif digunakan dalam pembelajaran mengidentifikasi unsur intrinsik cerpen Hadiah Seratus Cambukan karya Habiburrahman El Shirazy di Kelas XI SMA Negeri 1 Maja Tahun Ajar 2013/2014. Sementara itu, nilai korelasi yang diperoleh menunjukkan nilai korelasi yang tinggi.

\section{Simpulan}

Berdasarkan analisis dapat disimpulkan bahwa strategi PAIKEM dalam pembelajaran mengidentifikasi unsur intrinsik cerpen Hadiah Seratus Cambukan karya Habiburrahman El Shirazy efektif dapat meningkatkan kemampuan peserta didik. Hal tersebut dapat dilihat dari meningkatnya pemahaman peserta didik dalam mengidentifikasi unsur intrinsik cerpen. Sementara itu, berdasarkan hasil penghitungan dengan menggunakan rumus korelasi product moment antara nilai rata-rata pretest dan nilai rata-rata posttest menunjukkan nilai korelasi sebesar 0,760 atau berdasarkan pedoman pemberian interpretasi koefisien korelasi data menunjukkan korelasi yang tinggi. 


\section{Daftar pustaka}

Anggoro, T. et al. (2008). Metode Penelitian. Jakarta: Universitas Terbuka.

Djamarah, S. B. (2010). Guru \& Anak Didik dalam Interaksi Edukatif Suatu Pendekatan Teoretis Psikologis. Jakarta: Rineka Cipta.

Ibrahim \& Nana, S. (2010). Perencanaan Pengajaran. Jakarta: Rineka Cipta.

Mulyaningsih, I., Suwandi, S., Setiawan, B., \& Rohmadi, M. (2016). Model Pembelajaran Menulis Ilmiah Berbasis PARMI (Produksi, Atensi, Retensi, Motivasi, dan Inovasi) dan Penerapannya. Cirebon: Confident.

Mulyaningsih, I., Suwandi, S., Setiawan, B., \& Rohmadi, M. (2018). PARMI (Production, Attention, Retention, Motivation, and Innovation): An alternative to improving scientific writing skills. Lingua Cultura, 12(4), 317-321.

Mulyaningsih, I. \& Itaristanti, I. (2018). Pembelajaran Bermuatan HOTS (Higher Order Thinking Skills) di Jurusan Tadris Bahasa Indonesia. Indonesian Language Education and Literature, 4(1), 113 128.

Sanjaya, W. (2008). Strategi Pembelajaran Berorientasi Standar Proses Pendidikan. Jakarta: Kencana Prenada Media Group.

Shirazy, H. E. (2008). Di Atas Sajadah Cinta. Jakarta: Republika.

Somantri, A. (2010). Aplikasi Statistika dalam Penelitian. Bandung: CV Pustaka Setia.

Sudjana, N. (2008). Tuntunan Penyusunan Karya Ilmiah. Bandung: Sinar Baru Algensindo.

Sugiyono. (2010). Metode Penelitian Administrasi Dilengkapi dengan Metode R\&D. Bandung: CV Alfabeta. 